\title{
SOME ASPECTS CONGERNING THE ECONOMICS OF SOVEREIGN DEBT AND POSSIBLE INFLUENEES OF THE COVID-19 PANDEMIC
}

\author{
Liviu-Daniel DECEANU ${ }^{\text {a* }}$, Gabriela BODEA ${ }^{\mathrm{b}}$ \\ a),b) Babeș-Bolyai University, Faculty of Economics and Business Administration, \\ Cluj-Napoca, Romania
}

Please cite this article as:

Article History:

Deceanu, L.D. and Bodea, G., 2021. Some aspects concerning the economics of sovereign debt and possible influences of the COVID-19 pandemic.

Received: 3 November 2020 Accepted: 21 March 2021 Review of Economic Studies and Research Virgil Madgearu, 14(1), pp.17-29.

doi: 10.24193/RVM.2021.14.71.

Abstract: In the last 10 years, the sovereign debt crisis and its effects have made certain concepts, reserved until then only to specialists, to become elements of current language - public debt, sovereign debt, default, over-indebtedness, structural deficit, monetary policy, indebtedness ratios, sovereign debt effects, IMF intervention, willingness to pay... The indebtedness and over-indebtedness generated negative effects that affected not only the public finances, but also the economic agents (businesses) and the population, fueled by the lack of vision and responsibility of some governors. After the global economic crisis of 2008 and that of sovereign debt after 2010, a better control of indebtedness was tried, a more rigorous approach was implemented, but the Coronavirus pandemic that manifested itself in 2020 (and continues to do so) brought back to the forefront the problem of sovereign indebtedness and sovereign default.

Key words: sovereign risk; sovereign debt/default; sustainability; government policies; indebtedness ratios; COVID-19 pandemic

JEL Classification: F3; F34; GO1

(C) 2021 Alma Mater Publishing House. All rights reserved.

* Corresponding author. E-mail address: liviu.deceanu@econ.ubbcluj.ro. 


\section{References:}

1. Bulow, J., Reinhart, C., Rogoff, K. and Trebesch, C., 2020. The Debt Pandemic. IMF, Finance and Development, [online] September. Available at: <https://www.imf.org/external/pubs/ft/ fandd/2020/o9/debt-pandemic-reinhart-rogoff-bulow-trebesch. htm $>$ [Accessed 17 January 2021].

2. Deceanu, L., 2015. Some Considerations on Modern Sovereign Debt Approach. Review of Economic Studies and Research Virgil Madgearu, 8(1), pp. 51-65.

3. Garello, P., Spassova, V., 2006. L'endettement de l'Etat: stratégie de croissance ou myopie insouciante? IREF Working Papers: Studies on Debt and Growth, nr. 6, april.

4. Garello, P., Spassova, V., 2011. La crise de la dette souveraine française. IREF Working Papers: Studies on Debt and Growth, nr. 26, october.

5. Jones, M., 2020. How the coronavirus is crushing credit ratings, Reuters [online] Available at: <https://www.reuters.com/article/ushealth-coronavirus-ratings-graphic-idUSKCN24U18Y> [Accessed 17 January 2021].

6. Kobielarz, M., Uras, B., Eijffinger, S., 2015. Sovereign debt, bailouts and contagion in the Eurozone, [online] Available at: <https://voxeu. org/article/eurozone-debt-bailouts-and-contagion> [Accessed 17 January 2021].

7. Landau, J.P., 2012. Quelle politique pour la dette souveraine?. Banque de France (Dette publique, politique monétaire et stabilité financière). Revue de la stabilité financière, 16, april.

8. Lazard financial advisory, 2020. La dette des Etats - avis de turbulence, [online] Available at: <www.lazard.com> [Accessed 17 January 2021].

9. Monnier, J.M., 2017. Parlons dette. Paris: La Documentation française.

10. Reinhart, C. and Rogoff, K., 2009. This time is different. Eight Centuries of Financial Folly. Princeton: Princeton University Press.

11. Reinhart, C. and Rogoff, K., 2010. Growth in a Time of Debt. NBER Working Paper 15639, National Bureau of Economic Research, Inc.

12. Schumacher, J., Trebesch, C. and Enderlein, H., 2018. Sovereign defaults in court. ECB Working Paper Series, no 2135. 
Deceanu, Bodea, ...THE Economics of Sovereign DebT...

13. Reuters, 2020. Sovereign default risks to rise further in 2021: Goldman Sachs, [online] Available at: <https://www.reuters.com/ article/us-emerging-debt-debtrenegotiation-idINKBN27C1SE $>$ [Accessed 17 January 2021].

14. ${ }^{* * *}$, Country List Government Debt to GDP, [online] Available at: $<$ https://tradingeconomics.com/country-list/government-debt-togdp $>$ [Accessed 17 January 2021].

15. ${ }^{* *}$, Trade shows signs of rebound from COVID-19, recovery still uncertain [online] Available at: <https://www.wto.org/english/ news_e/pres20_e/pr862_e.ht> [Accessed 17 January 2021]. 